\title{
Hijaiyah Letter Interactive Learning for Mild Mental Retardation Children using Gillingham Method and Augmented Reality
}

\author{
Irawan Afrianto ${ }^{1}$, Agung Faishal Faris ${ }^{2}$, Sufa Atin ${ }^{3}$ \\ Departement of Informatics Engineering \\ Universitas Komputer Indonesia \\ Bandung, Indonesia
}

\begin{abstract}
Assistive technology for children with special needs is a problem that is interesting to study. Collaboration between methods and latest technology can be used as a learning aid for them. Learning of Hijaiyah letters is the first step to being able to read the Holy Qur'an. Mentally retarded children have IQs below the average normal child, so their learning process is slower and requires special methods. This study aims to develop an application by using the Gillingham and augmented reality methods to help mentally retarded children recognize Hijaiyah letters. The Gillingham method uses a visual, auditory, kinestetic, and tactile (VAKT) approach, that can be used to facilitate mentally retarded children. While augmented reality is used to develop more interesting and interactive applications. Based on the results of research and testing, it can be concluded that the learning application that was built can improve children's memory and understanding of Hijaiyah letters, The results of the pretest and posttest testing, showed an increase of $12 \%$ for children who were difficult to receive learning material and $6 \%$ for children who are classified as easy to receive learning material.
\end{abstract}

Keywords-Hijaiyah; intercative learning; mild retarded child; Gillingham; VAKT; augmented reality

\section{INTRODUCTION}

Children with mental retardation are children with limited conditions of development. The ability to learn is different from other normal children. Certain assistive methods and technologies are needed to support the teaching of children with special needs. This needs to combine the ability of special schools that handle mentally disabled children with assistive technology that can be used in learning [1].

The method that is widely used in helping children with special needs in letter recognition is the gillingham method. This method uses a multisensory mechanism to provide learning stimuli in the form of sounds, images and flavors to adapt the letters [2]. The Gillingham method is oriented to sound and letter links. Each letter is taught using a multisensory approach. Multisensory approaches used are visual, auditory, kinesthetic, and tactile (VAKT) [3]. Studies related to the VAKT approach have been carried out for children with special needs, such as the application of VAKT to deaf children [4], the application of VAKT to autistic children [5], and the implementation of VAKT in mentally disabled children [6].
The assistive technology used in helping children with special needs such as mental retardation is the development of hardware and software tailored to the abilities possessed by these children [7]. Other assistive technologies center on varied sound processing and displays [8], while other researchers reveal the use of assistive technologies that are selfmanagement tools that are beneficial for mentally disabled people in completing their daily activities [9]. The mobile application is one of the potential solutions for the development of learning for children with special needs, this is shown in research on the use of palmtops for mentally disabled people [10], the MARBEL mobile application for letter recognition learning for mild mental retardation sufferers [11] and android-based motorbike games for mentally disabled children [12]. Due to the limitations of integensia in mentally disabled children, learning models that are more adaptive to their abilities are needed. The interactive learning model is a learning model that can stimulate many activities for mentally disabled children [13]. This learning model can appear in the form of game-based learning for mentally disabled people developed with the help of computers [14] to produce games for mentally disabled children. Other studies use interactive technology and MAS platform games to help improve learning for deaf children [15]. Educational games for caring for mentally disabled children have also been developed and used to train children's motor skills and can be used by teachers as one of the learning media. [16]. Mobile applications and Augmented reality become a potential in the development of learning [17]. Augmented Augmented reality moves to become one of the technologies that has the ability to be used as the basis for developing learning applications for children [18]. The application of augmented reality can also provide flexibility in giving learning strategies [19], and is able to increase student learning motivation [20] and for children with special needs [21]. Augmented reality can also be used as a therapeutic medium for mentally disabled patients [22]. Other studies [23] show that augmented reality can help autistic patients and mentally disabled children to navigate to find a particular location / place.

The use of the VAKT method in this study aims to improve the ability of mildly retarded children in Hijaiyah letter learning. This study also aims to map the VAKT method to technology that allows for the development of interactive multimedia learning media by utilizing augmented reality 
technology, with the hope that the application developed can stimulate the visual, auditory, kinesthetic, and tactile senses of mildly retarded children so that they can easier to recognize and learn the letters Hijaiyah. In this study, the application will be tested on 2 groups of mild mentally retarded children to find out the changes in the ability of these children in Hijaiyah letter learning after using the application.

\section{RESEARCH METHOD}

The research method used in this research is divided into 4 stages, namely:

- The researcher collects the initial data according to the needs with a literature study in the form of journals and books related to the research that will be conducted. After the data is sufficient to support the research, the researcher will prepare the tools and materials needed for the next stage.

- At the planning stage, researchers make modeling applications that want to be made. The modeling started with system description, system architecture, functional analysis of application until application interfaces design.

- At the development stage, researchers will develop a model that has been made previously in the form of a program that is ready to be tested.

- The last stage is implementation and testing, the researcher implements the application on the appropriate device and tests how feasible the program has been made to be applied to mild mentally retarded children.

\section{RESUlt AND DisCUSSION}

This section describes the analysis of the current learning conditions, the application architecture developed, mapping the Gillingham method with the VAKT approach to the application developed, system modeling, design and testing of application built.

\section{A. Analysis of Current Learning Conditions}

From observations and interviews conducted by researchers, it was concluded that the current learning conditions still use conventional methods, namely teachers teaching students using ordinary teaching equipment and textbooks. Current procedures for teaching activities can be seen in Fig. 1 and 2.

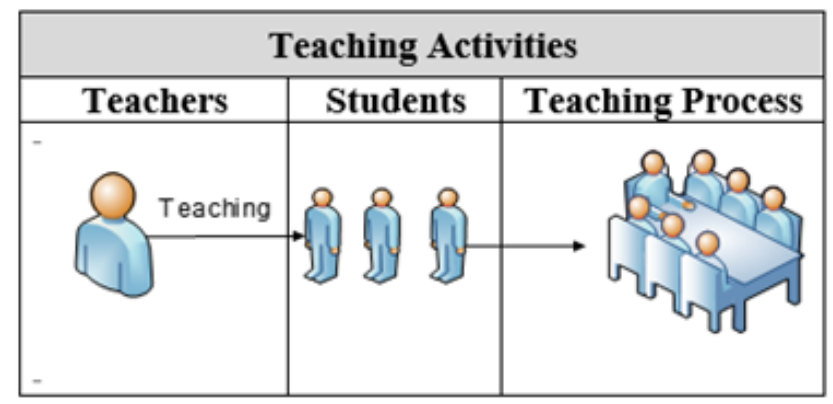

Fig. 1. Current Teaching Activity.

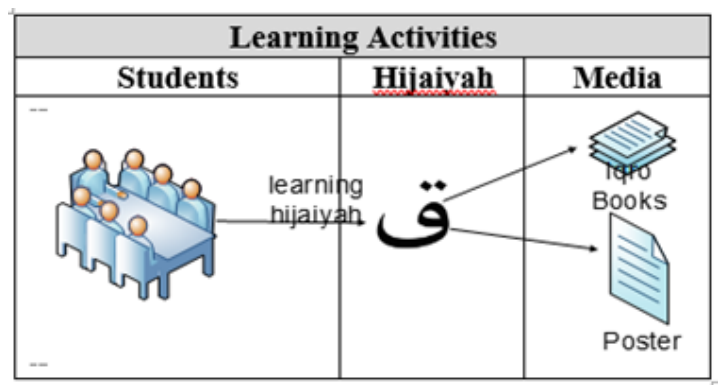

Fig. 2. Current Learning Hijaiyah Activity.

\section{B. Description of the Application}

The interactive learning Hijaiyah is a mobile-based application that is specifically for mild mentally retarded children learning Hijaiyah letters, with a structured and oriented method on sound and letter links. Where each letter is studied multisensory, starting from the sound, tracing the letters and copying letters. This learning method is called the Gillingham method. The VAKT Approach In this application is by introducing the Hijaiyah letters visually, with the help of sounds and images and thickening the letter points (movements) that have been taught. Each letter must be completed in order to proceed to the next letter. This application is made by using specific learning principles for mentally retarded children such as repetition and directed and gradual system flow. Augmented reality with marker frames is used to attract children to learn in more interesting ways. The application description that will be built can be seen in Fig. 3 .

\section{Analysis of System Architecture}

The system architecture is an overview of the application to provide the initial model of the application to be built [24] [25]. The system architecture that is built consists of several components of learning material presented with several modalities. The modalities used are visual (vision), auditory (hearing), kinesthetic (movement), and tactile (touch). The four are known as VAKT. System architecture in the development of this application introduces and teaches Hijaiyah letters to train children's memory with VAKT modalities- he Gillingham method, which is shown in Fig. 4.

The next step is to synchronize the Gillingham - VAKT method into the application that was built. Table I explains how the mapping of the Gillingham-VAKT method to the application was built.

\section{Analysis of Learning Outcomes}

The application that is built has a feature to store learning data in the form of student report cards. Student report cards will show the level of success of students in learning the material contained in the application. The student report card shows the number of correct answers and how many times the student is doing repetitions. Fig. 5 shows the student report card model in the application.

The learning results obtained by students are the values from the guessing feature and writing the letters Hijaiyah. Table II explains the calculations for the assessment of answers. 
TABLE I. IMPLEMENTATION GILLINGHAM METHOD ON APPLICATION

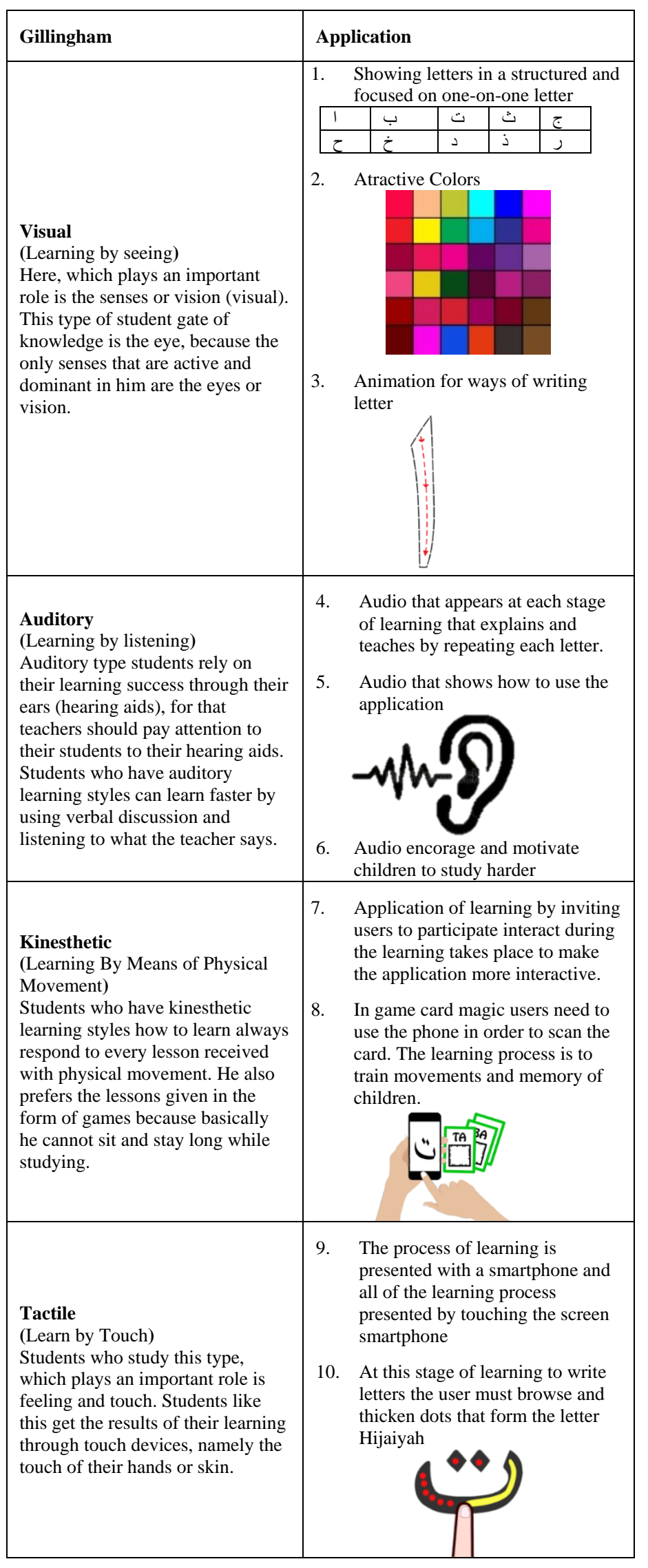

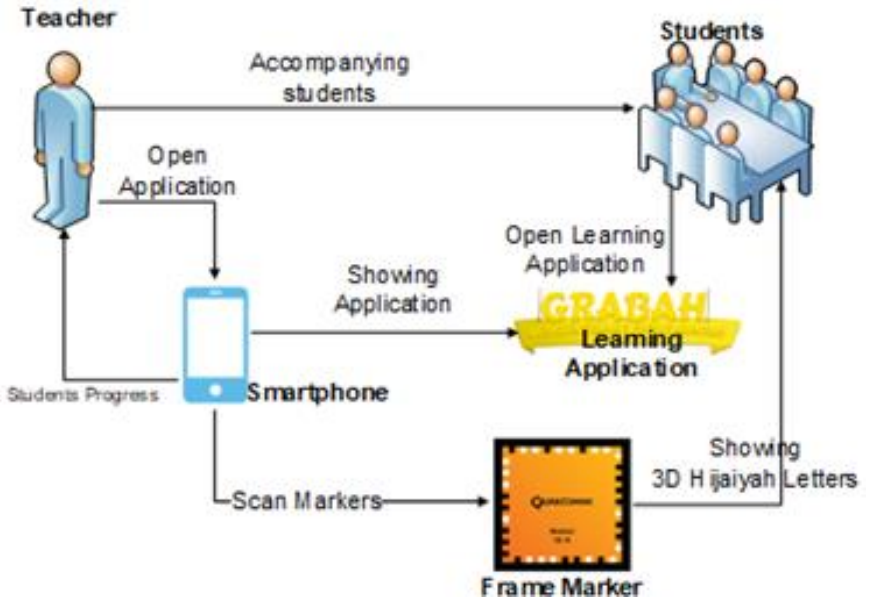

Fig. 3. Description of Application.

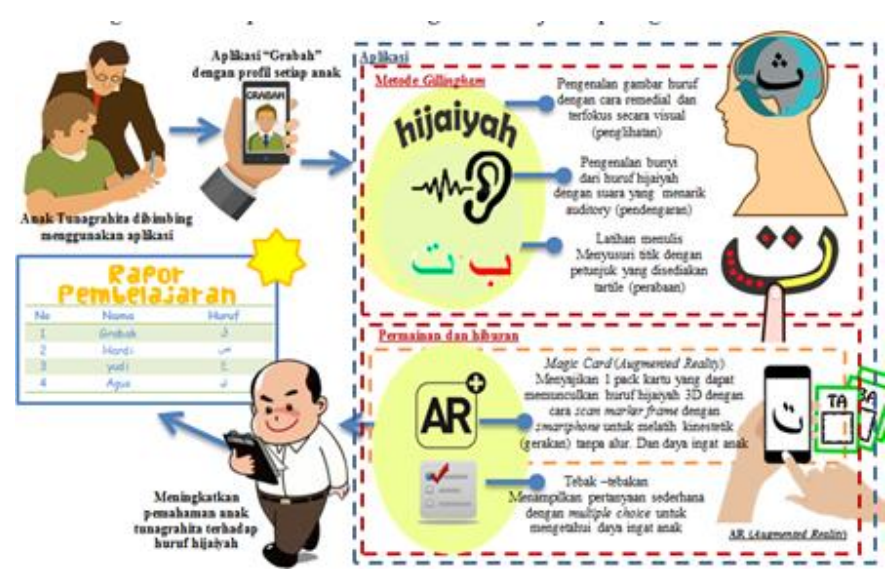

Fig. 4. System Architecture.

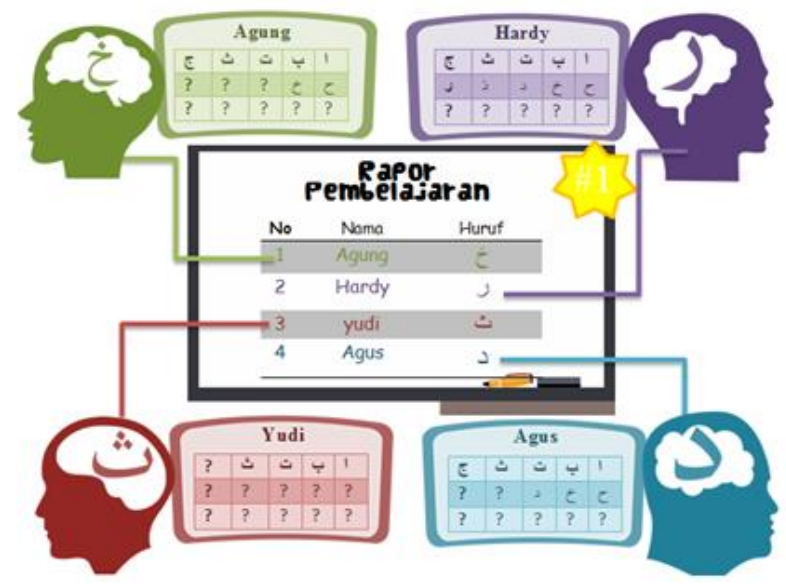

Fig. 5. Student Report Cards.

TABLE II. LEARNING SCORING

\begin{tabular}{|l|l|l|}
\hline Stages of Learning & $\begin{array}{l}\text { Number of Correct } \\
\text { Answers }\end{array}$ & System Action \\
\hline Quiz Multiple choice & $\begin{array}{l}\text { Answer correctly two } \\
\text { times }\end{array}$ & $\begin{array}{l}\text { Continue to the stage of } \\
\text { learning write Hijaiyah }\end{array}$ \\
\hline Write Hijaiyah & $\begin{array}{l}\text { Answer wrong } 3 \\
\text { times }\end{array}$ & $\begin{array}{l}\text { Repeating steps of } \\
\text { learning to write Hijaiyah }\end{array}$ \\
\hline
\end{tabular}


Wrong answers are limited to three times. Checkpoints are obtained from up to Hijaiyah letters that are open or understood and stored in student reports. In the report feature there will be a value in the form of numbers and last letters of the Hijaiyah that have been studied by each student.

\section{E. Analysis of Augmented Reality}

Augmented Reality is a real-time direct or indirect view of a physical real-world environment that has been enhanced/augmented by adding virtual computer-generated information to it. Its aims at simplifying the user's life by bringing virtual information not only to his immediate surroundings but also to any indirect view of the real-world environment [26]. The application built on Android, which has a feature to scan markers of Hijaiyah letters to produce an output in the form of a 3D object from the letters of the Hijaiyah. The flow of application of augmeted reality in the application that was built, can be seen in Fig. 6 .

Augmented reality developed in this application uses marker-based methods. The markers used are in the form of a collection of Hijaiyah letters card as shown in Fig. 7 and poster of the Hijaiyah letters in Fig. 8.

The markers will be scanned by the application to produce a 3D form of the letter Hijaiyah. The 3D model that appears is made tilting 130 degrees to adjust the user's eye. In Fig. 9, a 3D model is displayed that will appear from the scanned marker card.

The 3D model will also appear when the Hijaiyah letter poster is scanned using a built-in application. The 3D model that appears on the line aligns with the marker adjusting the user's eye point of view. Fig. 10 illustrates the appearance of a 3D model that will appear from the poster marker.

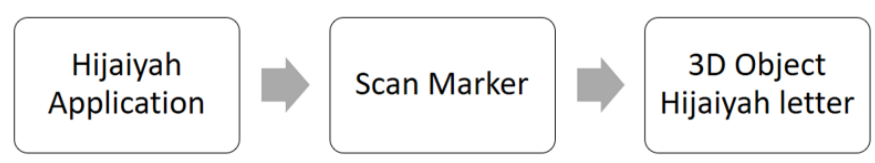

Fig. 6. Implementation of Augmented Reality.

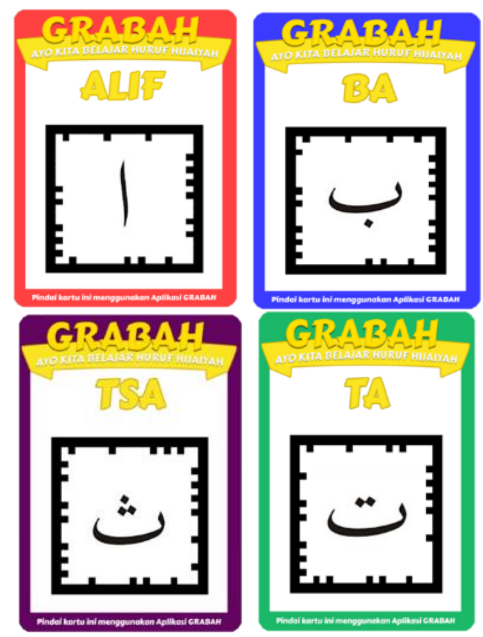

Fig. 7. Hijaiyah Letters Card Marker.

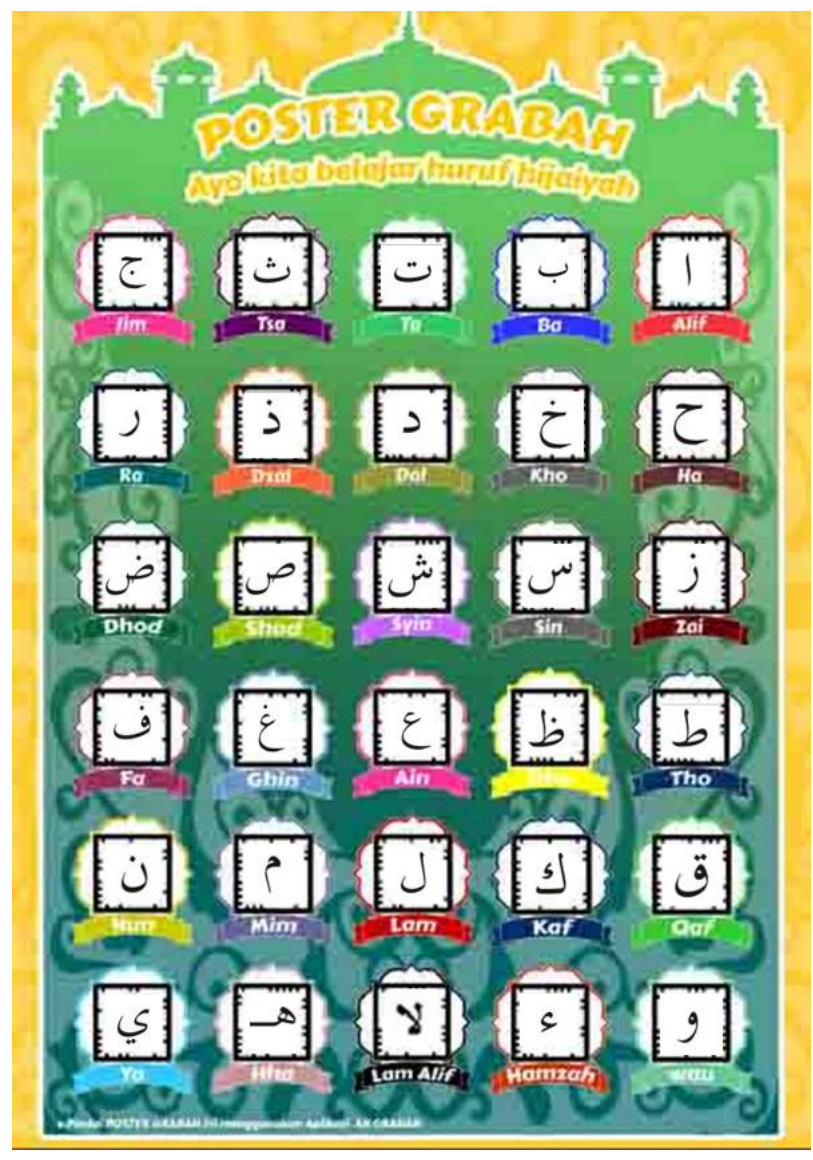

Fig. 8. Hijaiyah Letters Poster Marker.

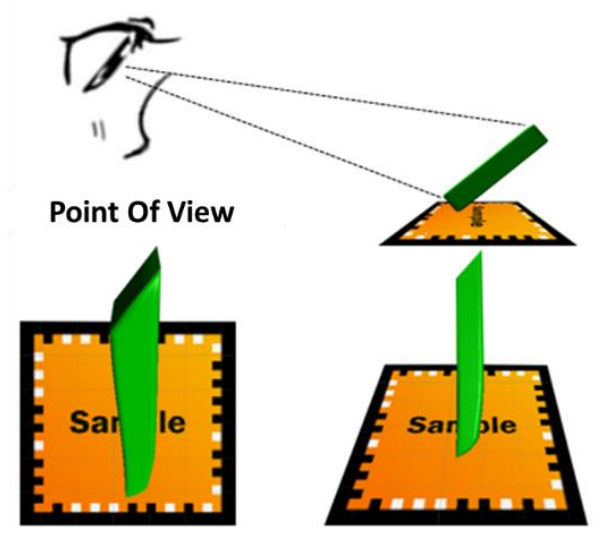

Fig. 9. 3D Model Display Card Hijaiyah Augmented Reality.

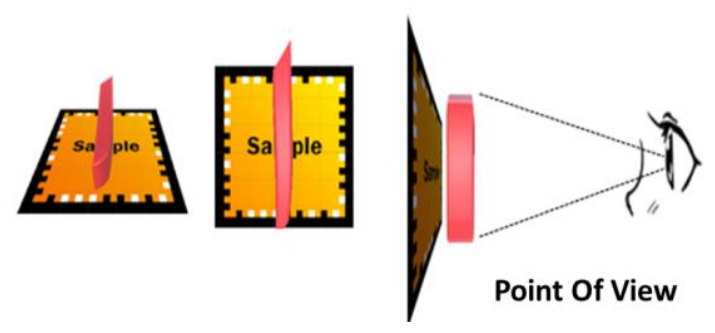

Fig. 10. 3D Model Display Poster Hijaiyah Augmented Reality. 


\section{F. Data Store Analysis}

Data storage in this application uses Playerprefs. Playerprefs is a database contained in the Unity application that can be used to store various kinds of data. In this application, playerprefs is used to store application user data, such as student names, letters that have been studied, and scores obtained by each student. Data storage workflow can be seen in Fig. 11.

\section{G. Application Modeling}

Modeling application used to facilitate the functional description that will be included in the application [27]. Application modeling is built using a use case diagram to explain the functional requirements contained in the application. Fig. 12 shows the use case diagram of the application that was built, as well as the description of each functional which can be seen in Table III.

\section{H. Annimation Design}

Animation is a motion picture that is formed from a set of objects (images) arranged regularly following the flow of motion that has been determined based on time [28]. The animation design applied in this application is to illustrate the animation of application characters as seen in Fig. 13, and animation for Hijaiyah letter movements in the application.

Animation in Hijaiyah letters is done by using the Tracking Point method where dots placed above the Hijaiyah letters are useful as a guide for writing Hijaiyah letters, as seen in Fig. 14.
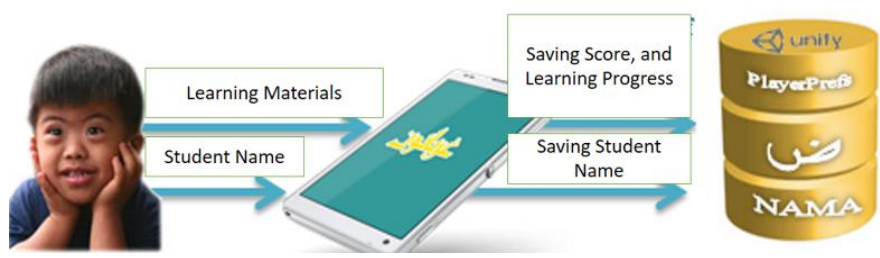

Fig. 11. Playprefs Data Storage.

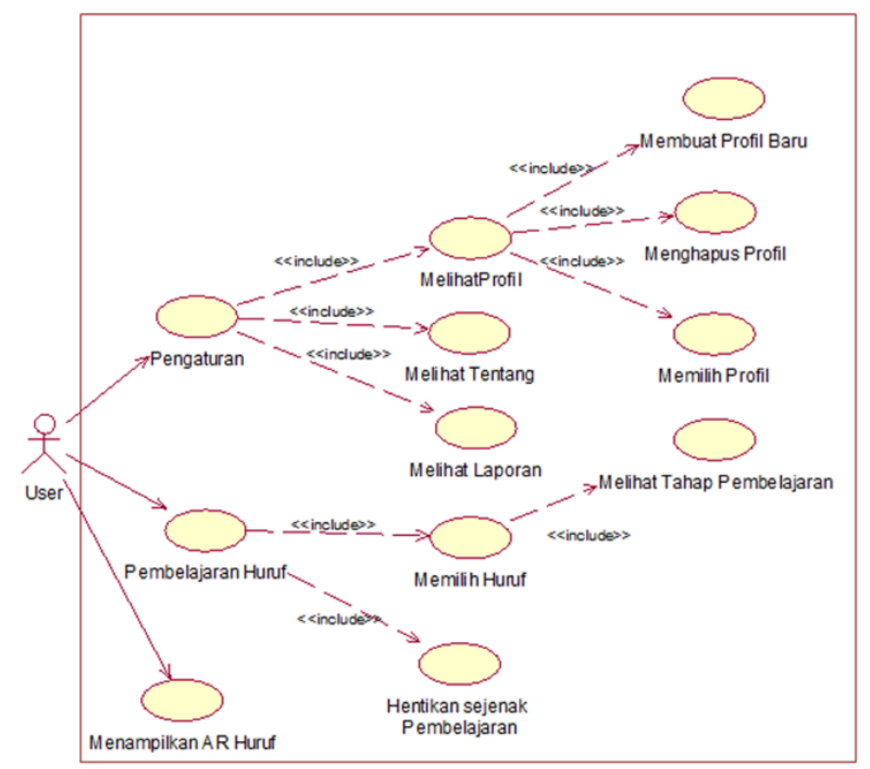

Fig. 12. Use Case Diagram Application.
TABLE III. USE CASE DEFINITIONS

\begin{tabular}{|c|c|c|}
\hline No & Use Case Name & Description \\
\hline 1 & Pengaturan & $\begin{array}{l}\text { The functionality is to go see the profile } \\
\text { settings, look about and see the learning report. }\end{array}$ \\
\hline 2 & Membuat Profil & $\begin{array}{l}\text { A functionality to create user application with a } \\
\text { new profile }\end{array}$ \\
\hline 3 & Menghapus Profil & $\begin{array}{l}\text { A functionality to delete a profile that was } \\
\text { made before }\end{array}$ \\
\hline 4 & Memilih Profil & $\begin{array}{l}\text { A functionality for to determine which profile } \\
\text { is active }\end{array}$ \\
\hline 5 & Melihat Profil & $\begin{array}{l}\text { A functionality for anyone to see the profile } \\
\text { name or an existing child }\end{array}$ \\
\hline 6 & Melihat tentang & $\begin{array}{l}\text { Is the functionality to view information about } \\
\text { the application maker }\end{array}$ \\
\hline 7 & Melihat laporan & $\begin{array}{l}\text { Is the functionality to see the extent to which } \\
\text { the child has been studying Hijaiyah }\end{array}$ \\
\hline 8 & Pembelajaran huruf & Functionality is to introduce the Hijaiyah \\
\hline 9 & Memilih huruf & $\begin{array}{l}\text { Hijaiyah functionality is to choose which one } \\
\text { will be studied. Could continue from last } \\
\text { Hijaiyah learned or repeat Hijaiyah has been } \\
\text { learned. }\end{array}$ \\
\hline 10 & $\begin{array}{l}\text { Memilih tahap } \\
\text { pembelajaran }\end{array}$ & $\begin{array}{l}\text { A functionality to choose from where the } \\
\text { checkpoint will repeat. From each chekpoint } \\
\text { consists of } 5 \text { letters Hijaiyah. }\end{array}$ \\
\hline 11 & $\begin{array}{l}\text { Hentikan sejanak } \\
\text { pembelajaran }\end{array}$ & $\begin{array}{l}\text { A pause functionality for learning and there is a } \\
\text { menu to get to the home page and the music } \\
\text { setting. }\end{array}$ \\
\hline 12 & $\begin{array}{l}\text { Menampilkan AR } \\
\text { huruf }\end{array}$ & $\begin{array}{l}\text { Is the functionality to display the augmented } \\
\text { reality feature or magic playing cards. }\end{array}$ \\
\hline
\end{tabular}

The tracking point method is used to animate Hijaiyah letters to show how to write the correct Hijaiyah letters. One example of the animation of Hijaiyah letters can be seen in Fig. 15.

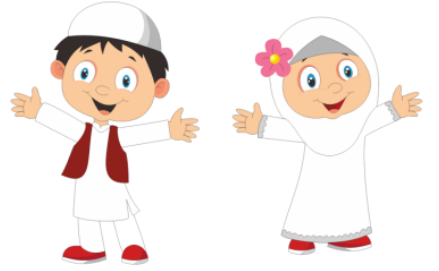

Fig. 13. Illustration of Character in Application.

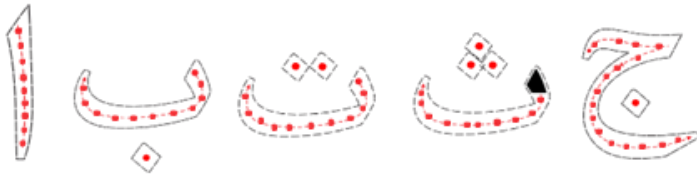

Fig. 14. Hijaiyah Letters Tracking Point Design.

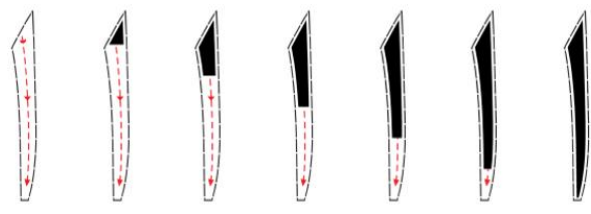

Fig. 15. Animated Hijaiyah Letters. 
TABLE IV. MAPPING POINTS HIJAIYAH LETTERS

\begin{tabular}{|c|c|c|}
\hline Hijaiyah Letter & Number of Points & Position $(\mathbf{x}, \mathbf{y}, \mathbf{z})$ \\
\hline Alif & 10 points & $\begin{array}{ll}\text { point[0] } & \text { position(-8,229,0); } \\
\text { point[1] } & \text { position }(-3,190,0) ; \\
\text { point[2] } & \text { position }(-1,150,0) ; \\
\text { point[3] } & \text { position }(2,103,0) \\
\text { point[4] } & \text { position }(5,63,0) ; \\
\text { point[5] } & \text { position }(6,17,0) ; \\
\text { point[6] } & \text { position }(7,-29,0) ; \\
\text { point[7] } & \text { position }(6,-73,0) ; \\
\text { point[8] } & \text { position }(4,-115,0) ; \\
\text { point[9] } & \text { position }(1,-160,0)\end{array}$ \\
\hline$B a$ & 13 points & $\begin{array}{l}\text { point[0] position }(164,143,0) ; \\
\text { point[1] position }(183,100,0) ; \\
\text { point[2] position }(180,54,0) ; \\
\text { point[3] position }(150,24,0) ; \\
\text { point[4] position }(95,6,0) ; \\
\text { point[5] position }(29,-4,0) ; \\
\text { point[6] position }(-30,-8,0) ; \\
\text { point[7] position }(-83,-7,0) ; \\
\text { point[8] position }(-138,4,0) ; \\
\text { point[9] position }(-181,34,0) ; \\
\text { point[10] position }(-193,84,0) ; \\
\text { point[11] position }(-185,124,0) ; \\
\text { point[12] position }(10,-144,0) ;\end{array}$ \\
\hline$T a$ & 13 points & $\begin{array}{l}\text { point[0] position }(162,138,0) ; \\
\text { point[1] position }(186,84,0) ; \\
\text { point[2] position }(167,34,0) ; \\
\text { point[3] position }(117,9,0) ; \\
\text { point[4] position }(59,-5,0) ; \\
\text { point[5] position }(0,-12,0) ; \\
\text { point[6] position }(-59,-14,0) ; \\
\text { point[7] position }(-115,-8,0) ; \\
\text { point[8] position }(-163,9,0) ; \\
\text { point[9] position(-192,51,0); } \\
\text { point[10] position }(-188,116,0) ; \\
\text { point[11] position }(48,188,0) ; \\
\text { point[12] position }(-37,189,0) ;\end{array}$ \\
\hline
\end{tabular}

With the tracking point method used, each Hijaiyah letter is mapped into points which later become a marker for the animation movement on the letter. Examples of mapping these points can be seen in Table IV.

\section{Implementation and Testing}

The final result of this study is an interactive learning application for mild mentally retarded children where the design application uses the VAKT approach and augmented reality. Some application interface can be seen in Fig. 16, 17, 18 and 19.

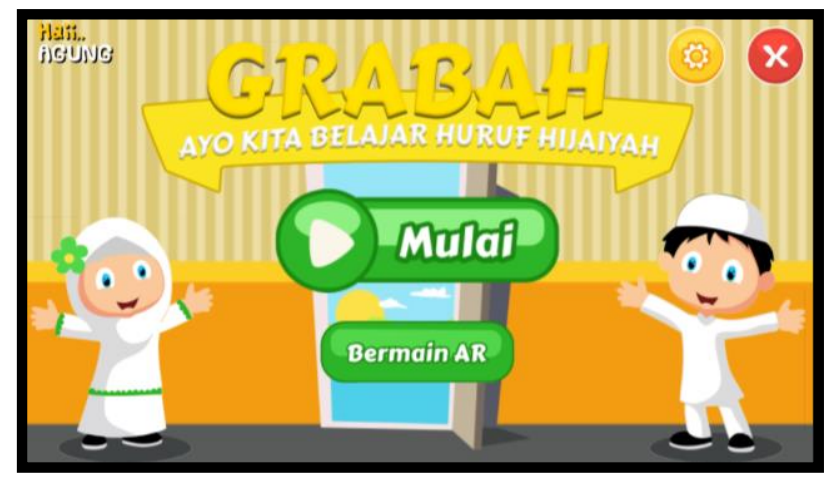

Fig. 16. Application Opening Interface.

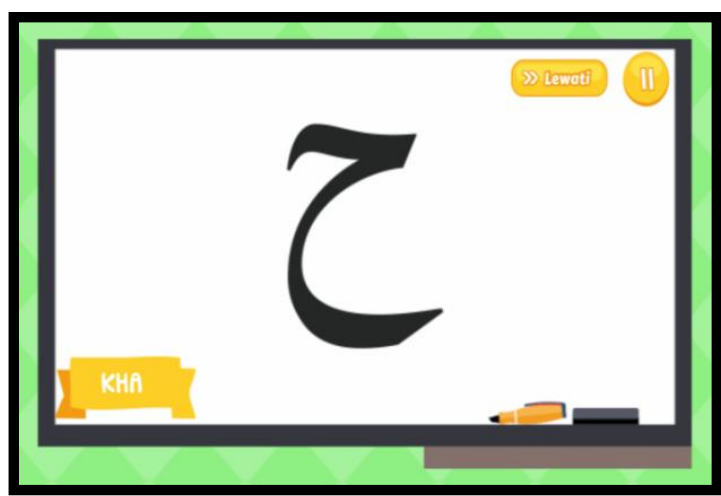

Fig. 17. Hijaiyah Letter Introduction.

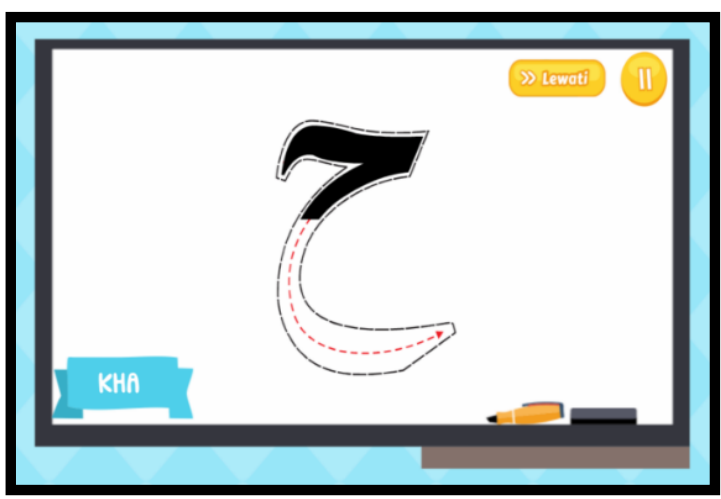

Fig. 18. Drawing Hijaiyah Letter.

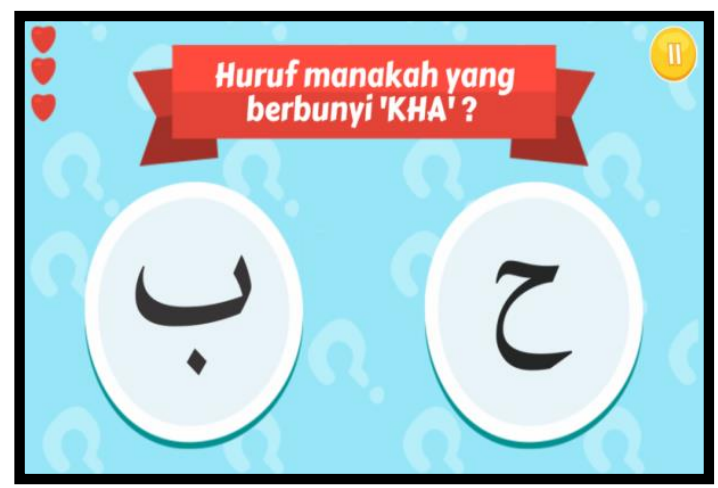

Fig. 19. Game the Correct Letters.

Application testing is conducted in two ways, namely, testing the accuracy of the marker used, and testing the ability of students using the application. The results obtained from the marker-augmented reality test concluded that from 30 markers of Hijaiyah letters in the form of cards and posters, $100 \%$ of the markers can be scanned and produce 3D objects Hijaiyah letters. Testing students' abilities, using the pretest and posttest method. The pretest method is used to measure students' abilities before using the application, while the posttest method is used after students use the application. Application testing is carried out on 20 students divided into two groups, namely, students who have difficulty concentrating and students who are easy to concentrate. The results of the pretest and posttest tests on students who have difficulty concentrating can be seen in Fig. 20(a), while the results of testing for students who are easy to concentrate can be seen in Fig. 20(b). 


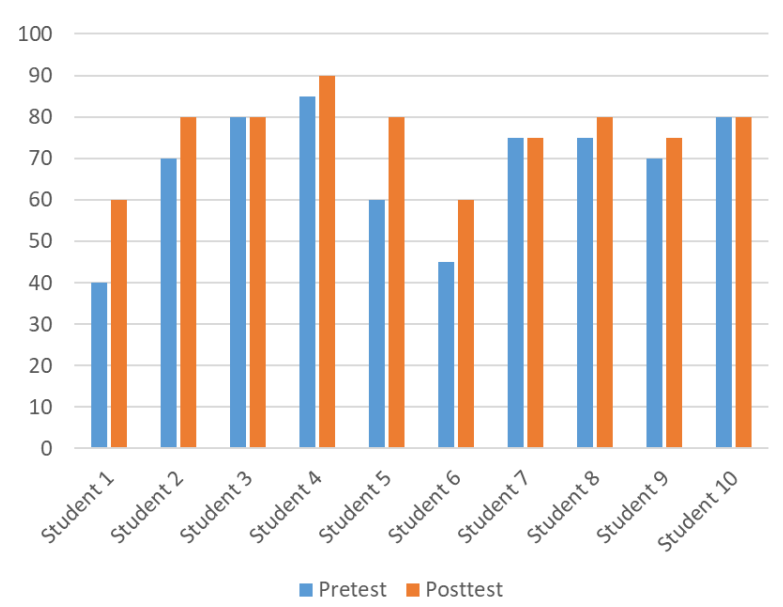

(a)

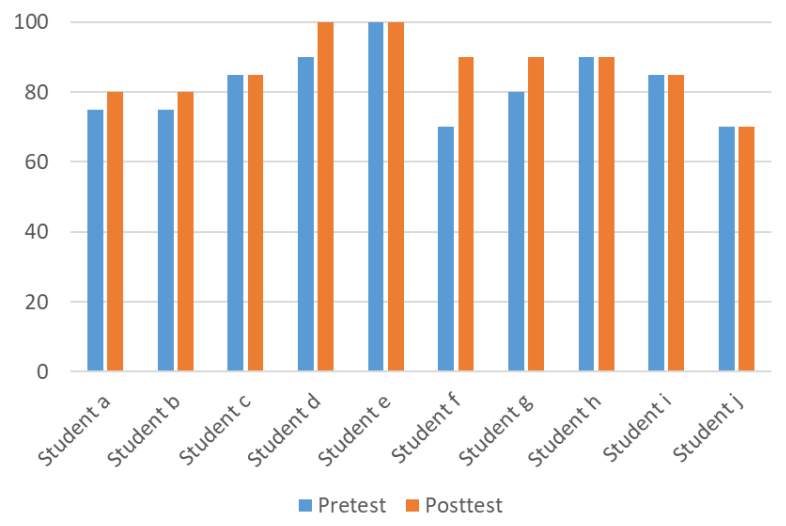

(b)

Fig. 20. Pretest and Posttest Results.

From the results of these tests, the average is calculated to determine changes in students' abilities before and after using the application, shown in Table V.

The results of the research conducted gave results of improvement in both test groups of mild mentally retarded children. Children who have difficulty concentrating have increased by $12 \%$, while for children who are easy to concentrate, there is a $6 \%$ increase in Hijaiyah letter learning. Likewise with the results of previous studies that by using multisensory-VAKT methods, there is an increase in the learning of children with special needs, in the study [29] the reading ability of kindergarten students increased by $14 \%$, in the other study the reading ability of elementary students with dyslexia increased in the number of word recognition, reading time, and the number of words read per minute [30], and the development of the ability to recognize flat waking in children with cerebral palsy increased with a percentage of 66.6\% [31].

TABLE V. RESULTS AFTER USING THE APPLICATION

\begin{tabular}{|l|l|l|c|l|}
\hline $\begin{array}{l}\text { Children } \\
\text { Group }\end{array}$ & $\begin{array}{l}\text { Pretest } \\
\text { Average }\end{array}$ & $\begin{array}{l}\text { Posttest } \\
\text { Average }\end{array}$ & $\begin{array}{l}\text { Increase } \\
\text { Score }\end{array}$ & $\begin{array}{l}\text { Percentage } \\
(\%)\end{array}$ \\
\hline $\begin{array}{l}\text { Difficulty } \\
\text { concentrating }\end{array}$ & $680 / 10=68$ & $760 / 10=76$ & 8 & $12 \%$ \\
\hline $\begin{array}{l}\text { Easy } \\
\text { concentrating }\end{array}$ & $820 / 10=82$ & $870 / 10=87$ & 5 & $6 \%$ \\
\hline
\end{tabular}

\section{CONCLUSIONS}

Based on the results of the implementation and testing carried out, it can be concluded that the Gillingham method with the VAKT approach and augmented reality can be developed into an interactive learning application that is able to improve the ability of students with mild mental disabilities. This is indicated by an increase in capacity of $12 \%$ for students who have difficulty concentrating and an increase of $6 \%$ for students who are easy to concentrate on the material and learning Hijaiyah letters.

For further work, it is necessary to consider other technologies in developing the application in the future, mapping the VAKT method that is more varied in order to produce more diverse learning variations that are in accordance with the ability of children with mild retardation.

\section{ACKNOWLEDGMENT}

Our thanks to the Caringin Bandung Special School (SLB) dan UNIKOM, which became a partner in this research, became a place for data searching, discussion, implementation and testing of application.

\section{REFERENCES}

[1] M. L. Wehmeyer, 1999, "Assistive technology and students with mental retardation: utilization and barriers", Journal of Special Education Technology, 14(1), pp.48-58, 1999.

[2] A. Gillingham and B.W. Stillman, The gillingham manual. Cambridge, MA: Educators. 1997.

[3] S. Suhatli, "Meningkatkan kemampuan menulis kata melalui metode gilingham bagi anak kesulitan belajar kelas ii di sd negeri 05 kapalo koto", Jurnal Penelitian Pendidikan Khusus, 4(3). 2017.

[4] V.O. Julita, "Efektivitas metode vakt untuk meningkatkan hafalan surah al-kautsar bagi anak tunarungu (penelitian single subject research di kelas v slb luak nan bungsu kota payakumbuh)", Jurnal Penelitian Pendidikan Khusus, 4(3). 2017.

[5] R. Afriliya, "Penggunaan metode visual auditori kinestetik taktil (vakt) terhadap pemahaman kosa kata anak autis", Jurnal Pendidikan Khusus, 7(1). 2015.

[6] D. Kumilasari, M. Iswari, and G. Sumekar, "Meningkatkan kemampuan menulis huruf vokal (a, i, u, e, o) melalui metode vakt bagi anak tunagrahita sedang di slb talawi sawahlunto", Jurnal Penelitian Pendidikan Khusus, 6(1). 2017.

[7] E.A. Draffan, D.G. Evans, and P. Blenkhorn, "Use of assistive technology by students with dyslexia in post-secondary education", Disability and Rehabilitation: Assistive Technology, 2(2), pp.105-116. 2007.

[8] K.M. Wilkinson and S. Hennig, "The state of research and practice in augmentative and alternative communication for children with developmental/intellectual disabilities", Mental retardation and developmental disabilities research reviews, 13(1), pp.58-69. 2007.

[9] L.C. Mechling, "Assistive technology as a self-management tool for prompting students with intellectual disabilities to initiate and complete daily tasks: A literature review", Education and Training in Developmental Disabilities, 42(3), p.252. 2007.

[10] S.E Stock, D.K. Davies and M.L Wehmeyer, "Evaluation of an application for making palmtop computers accessible to individuals with intellectual disabilities", Journal of Intellectual and Developmental Disability, 31(1), pp.39-46. 2006.

[11] F.A Nurcholis and N. Azizah, "Pengaruh mobile application marbel huruf terhadap kemampuan mengenal huruf anak tunagrahita ringan kelas ii di slb negeri wonogiri”, JPK (Jurnal Pendidikan Khusus), 13(2), pp.41-56. 2017.

[12] M.R. Wibisono and Y. Findawati, "Game Motorik Untuk Pendidikan Anak Berkebutuhan Khusus (Tuna Grahita) Berbasis Android", Informatika, I (6), pp.20-29. 2010. 
[13] S. Syahruddin, M.S Saleh,. and A. Rizal, "Peningkatan koordinasi mata tangan melalui model pembelajaran berbasis bermain bagi anak tuna grahita”, In Seminar Nasional Lembaga Penelitian UNM (Vol. 2, No. 1). 2017.

[14] C.S. Lanyi and D.J. Brown, "Design of serious games for students with intellectual disability", IHCI, 10, pp.44-54. 2010.

[15] R. Colomo-Palacios, F. Paniagua-Martín, Á. García-Crespo and B. RuizMezcua, "Technology enhanced learning for people with intellectual disabilities and cerebral paralysis: The MAS platform", In International Conference on Technology Enhanced Learning (pp. 11-17). Springer, Berlin, Heidelberg. 2010.

[16] F.Y. Al Irsyadi, S.L. Sholihah and E. Sudarmilah, "Game edukasi merawat diri untuk anak tunagrahita tingkat sekolah dasar berbasis kinect xbox 360", Simetris: Jurnal Teknik Mesin, Elektro dan Ilmu Komputer, 7(2), pp.693-700. 2016.

[17] E. FitzGerald, R. Ferguson, A. Adams, M., Gaved, Y. Mor and R., Thomas, "Augmented reality and mobile learning: the state of the art", International Journal of Mobile and Blended Learning (IJMBL), 5(4), pp.43-58. 2013.

[18] D. Incarean, M.B. Alia, N.D.A. Halim and M.H.A. Rahman, "Mobile augmented reality: the potential for education", Procedia-social and behavioral sciences, 103, pp.657-664. 2013.

[19] P.Y. Chao and G.D. Chen, "Augmenting paper-based learning with mobile phones", Interacting with Computers, 21(3), pp.173-185. 2009.

[20] Á. Di Serio, M.B. Ibáñez,. and C.D. Kloos, "Impact of an augmented reality system on students' motivation for a visual art course", Computers \& Education, 68, pp.586-596. 2013.

[21] C.Y. Lin, H.C. Chai, J.Y. Wang, C.J. Chen, Y.H. Liu, C.W. Chen, C.W. Lin and Y.M., Huang, "Augmented reality in educational activities for children with disabilities", Displays, 42, pp.51-54. 2016.

[22] A.G.D. Correa, I.K. Ficheman, M. do Nascimento and R. de Deus Lopes, "Computer assisted music therapy: A case study of an augmented reality musical system for children with cerebral palsy rehabilitation", In
2009 Ninth IEEE International Conference on Advanced Learning Technologies (pp. 218-220). IEEE. 2009.

[23] D. McMahon, D.F. Cihak, and R.Wright, "Augmented reality as a navigation tool to employment opportunities for postsecondary education students with intellectual disabilities and autism", Journal of Research on Technology in Education, 47(3), pp.157-172. 2015.

[24] I. Afrianto, L. Warlina, S. Atin and A. Heryandi, "Framework of journal aggregator in indonesia", In International Conference on Business, Economic, Social Science and Humanities (ICOBEST 2018). Atlantis Press. November, 2018.

[25] A. Finandhita,. and I. Afrianto,"Development of e-diploma system model with digital signature authentication", In IOP Conference Series: Materials Science and Engineering (Vol. 407, No. 1, p. 012109). IOP Publishing. August, 2018.

[26] J. Carmigniani, B. Furht, M. Anisetti, P. Ceravolo, E. Damiani and M. Ivkovic, "Augmented reality technologies, systems and applications. Multimedia tools and applications", 51(1), pp.341-377. 2011.

[27] I. Afrianto, and S. Atin, "The Journal Aggregator System Concept Using User Centered Design (UCD) Approach", International Journal of New Media Technology, 5(2), pp.71-75. 2018.

[28] K. Fujisawa, T. Inoue, Y. Yamana, and H. Hayashi, "The effect of animation on learning action symbols by individuals with intellectual disabilities", Augmentative and Alternative Communication, 27(1), pp.53-60. 2011.

[29] A.C. Dewi and S. Aryanti, "Meningkatkan kemampuan membaca permulaan melalui metode multisensori pada kelompok b tk ygws semarang", Media Penelitian Pendidikan: Jurnal Penelitian dalam Bidang Pendidikan dan Pengajaran, 11(1). 2017.

[30] M.D. Komalasari, "Efektivitas metode multisensori dalam meningkatkan kemampuan membaca pada peserta didik disleksia di sekolah dasar", Jurnal Elementary School, 4(1), pp.14-19. 2017.

[31] N. Sutisna and A. Rahmawati, "Pengaruh metode vakt terhadap peningkatan kemampuan mengenal bangun datar pada anak cerebral palsy", Pedagogia, 16(2), pp.168-179. 2018. 